\title{
British Government and Politics
}




\section{Books in the Politics Study Guides series}

British Government and Politics: A Comparative Guide (2nd edition) Duncan Watts

US Government and Politics (2nd edition)

William Storey

International Politics: An Introductory Guide

Alasdair Blair and Steven Curtis

Devolution in the United Kingdom (2nd edition)

Russell Deacon

Political Parties in Britain

Matt Cole and Helen Deighan

Democracy in Britain

Matt Cole

The Changing Constitution

Kevin Harrison and Tony Boyd

The Fudiciary, Civil Liberties and Human Rights

Steven Foster

The Prime Minister and Cabinet

Stephen Buckley

Britain and the European Union

Alistair Jones

Pressure Groups

Duncan Watts

The Politics of Northern Ireland

Joanne McEvoy

The UK Parliament

Moyra Grant

The American Presidency

Duncan Watts

Electoral Systems and Voting in Britain

Chris Robinson

Political Communication

Steven Foster

euppublishing.com/series/posg 


\title{
British Government andPolitics
}

\author{
A Comparative Guide
}

\author{
Second edition
}

Duncan Watts

EDINBURGH

University Press 
(C) Duncan Watts, 2006, 2012

First edition published 2006

Edinburgh University Press Ltd

22 George Square, Edinburgh EH8 9LF

www.euppublishing.com

Typeset in $11 / 13$ pt Monotype by

Servis Filmsetting Ltd, Stockport, Cheshire, and

printed and bound in Great Britain by

CPI Group (UK) Ltd, Croydon CR0 4YY

A CIP record for this book is available from the British Library

ISBN 9780748644940 (hardback)

ISBN 9780748644544 (paperback)

ISBN 9780748644551 (webready PDF)

ISBN 9780748654949 (epub)

ISBN 9780748654932 (Amazon ebook)

The right of Duncan Watts to be identified as author of this work has been asserted in accordance with the Copyright, Designs and Patents Act 1988. 